\title{
Phytochemical Characterization of Ethanolic Extracts of the Leaves of Zanthoxylum Caribaeum Lam and Evaluation of Antimicrobial Activity Against Burkholderia Glumae
}

\section{GIOVANNI CHAVES-BEDOYA, EDGAR JOEL VERA, LUZ YINETH ORTIZ-ROJAS*}

Fitobiomol Research Group. Universidad Francisco de Paula Santander. Av. Gran Colombia No. 12E96 Barrio Colsag, Cúcuta, Colombia.

\begin{abstract}
Phytochemical analysis of the leaf extract of Zanthoxylum caribaeum Lam (Family Rutaceae) collected in the La Garita district, Municipality of Los Patios in Norte de Santander, Colombia, is reported. Ethanolic extracts by simple maceration were concentrated at reduced pressure. Secondary metabolites found in preliminary identification demonstrated the presence of of alkaloids, tannins, carotenoids, anthocyanins, coumarins, cardiotonics, flavonoids, quinones, saponins, sesquiterpenlactones, and triterpenoids. Gas chromatography mass spectrometry analysis identified the presence of ten compounds, with $\alpha$-trans-farnesene (33.5\%) as the main constituent, followed by trans- $\beta$ caryophyllene (28.1\%), S-cadinene (9.7\%), caryophyllene oxide (8.3\%) and $\gamma$-muurolene (8.1\%). Some of these compounds have been reported with biological properties such as antiparasitic, antimicrobial or cytotoxic, so Zanthoxylum caribaeum is a promising species in the Department of North Santander as a source of compounds chemicals with important biological activity.
\end{abstract}

Keywords: phytochemistry, Zanthoxylum caribaeum, secondary metabolites, B. Glumae

\section{Introduction}

Colombia has a diversity of climates and environmental conditions, which favor the growth and dispersion of different varieties and species of plants. In the department of Norte de Santander, characterized by having a tropical dry forest, some botanical classification studies have been carried out. However, phytochemical studies are relatively scarce. The importance of phytochemical composition studies lies in being able to determine the presence of secondary metabolites with possible biological activity [1]. Plant secondary metabolites are chemical compounds produced by the plant cell through metabolic pathways derived from primary metabolic pathways and have been shown to have different biological effects. Antibiotic, antifungal and antiviral properties have been described. These metabolites are classified according to their chemical structure [2].

Among the plant resources available to the Department of Norte de Santander, is the Family Rutaceae, which comprises about 160 genera and about 1900 species [3]. The Rutaceae family presents alkaloids and coumarins, secondary metabolites with biological activities such as antitumor, astringent, analgesic, antiplatelet aggregation, antimicrobial, leishmanicida, cytotoxic, anticoagulant and antimalarial [4]. The presence of sesquiterpenes such as ( $\beta$-caryophyllene, $\alpha$-caryophyllene, seline-3.7(11)diene) in species of the Rutaceae family was evidenced in Raputia heptaphylla [5]. Zanthoxylum caribaeum Lam, (Rutaceae) known as "zorruno" in Norte de Santander is found as shrubs or deciduous tree, with thorny stems and brown twigs. Ethanolic extracts from Zanthoxylum species have shown biological activity against different pests or pathogens; in example against Sitophilus zeamais Mots, Callosobruchus maculatus F and C. Maculatus [6], acaricidal activity [7, 8], biological activity against Gram-positive bacteria [9], and allelopathic properties [10]. Z. Monophyllum contains metabolites with biological activity against fungi affecting humans such as Aspergillus terreus, Aspergillus flavus, Penicillium digitatum, Penicillium funiculosum, Penicillium citinum, Paecilomyces and Candida albicans [11]. Finally, due the phytotoxic potential of Zanthoxylum affine has been suggested as a possible natural herbicide [12].

*email: luzyinethor@ufps.edu.co 
Despite the remarkable use of $Z$. caribeaum and its wide presence in different regions of Norte de Santander, there is a lack of studies related to its phytochemical composition and biological activity that allow in the future the development of medicines or compounds for the control of pathogens that affect the population or crop plants such as Burkholderia glumae, which causes bacterial panicle blight (BPB) in rice crops [13]. In this study by phytochemical analysis of $Z$. caribeaum extracts, it was possible to determine the presence of compounds such as alkaloids, tannins, saponins and flavonoids among other secondary metabolites being this tree a valuable source of active natural constituents of interest in the chemical or pharmaceutical industry. The ethanolic extracts of $Z$. caribeaum leaves was investigated against B. Glumae.

\section{Materials and methods}

\subsection{Ethanolic extract of $Z$. caribeaum}

Z. caribaeum Lam (Figure 1) samples with collection number COL:648, were collected at the La Garita, Norte de Santander, at 520 meters above sea level and an average temperature of $28^{\circ} \mathrm{C} .100 \mathrm{~g}$ of dried, powder-free, crushed leaves were used and added in $200 \mathrm{~mL}$ of ethanol (Merck, Germany). The mixture was left 72h in total darkness on a shaker (MAXQ 4450, Thermo ScientificTM. Marieta, United States), $35^{\circ} \mathrm{C}$ and $100 \mathrm{rpm}$. The extract was filtered under vacuum with filter paper (Qual. dia. 125mm, BOECO, Germany) using a vacuum pump (DOSIVAC, Buenos Aires, Argentina). The ethanolic extract was concentrated at reduced pressure using a rotary evaporator (IKA®RV10, Wilmington, United States) at 50rpm, $150 \mathrm{mbar}$ and $40^{\circ} \mathrm{C}$. The concentrated extract was stored in amber bottles at $4^{\circ} \mathrm{C}$ for further analysis.

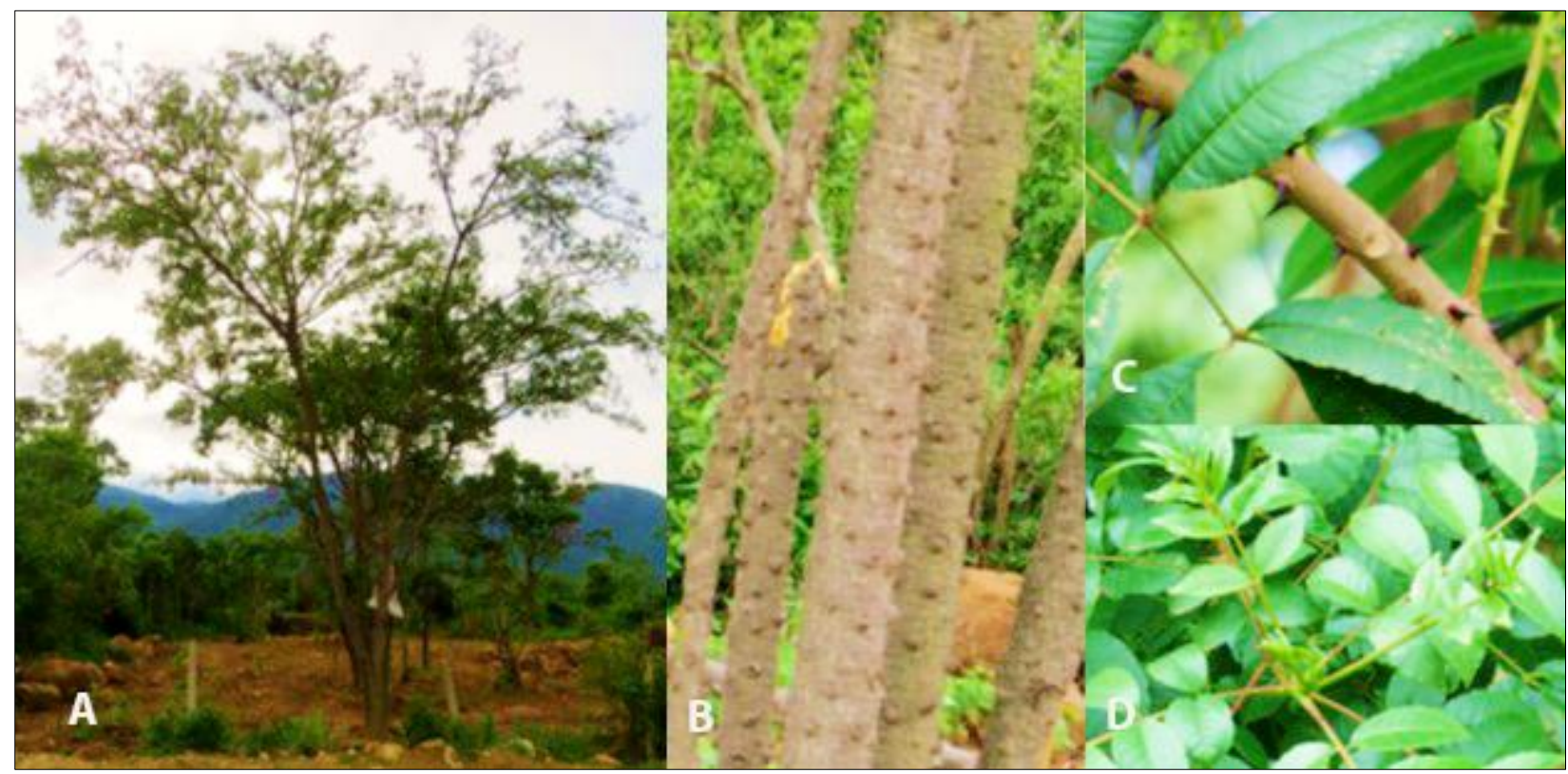

Figure 1. A) Z. Caribeaum tree in Norte de Santander, Colombia. B) Stem with prickles. C. Z. caribeaum leaves with crenated edge. D. Young glabrous branches, with or without stingers. D

\subsection{Thin layer chromatography (TLC)}

To determine the best separation eluent, thin layer chromatography runs of the extract were performed using different mobile phases: Ethyl hexane-acetate $(95: 5 \mathrm{v} / \mathrm{v})$, ethyl-propanol acetate $(9: 1)$ and ethyl petroleum-acetate ether (7:3). All chemical reactants were from Merck, Germany the plates were run with the extract and revealed with ultraviolet light at a wavelength of 254 and $365 \mathrm{~nm}$ respectively to determine by fluorescence the presence of secondary metabolites. 


\subsection{Identification of secondary metabolites by gas chromatography-mass spectrometry (GC-MS)}

HPLC methanolic extract ( $80 \%)$ from the leaves and bark of Z caribaeum was analyzed. The chromatographic analysis was performed on an AT 6890 Series Plus gas chromatograph (Agilent Technologies, MSD 5973, Santa Clara, United States), operated in full scan mode. The column used in the analysis was DB-5MS (5\%-phenyl-poly (methylsiloxane), $60 \mathrm{~m} \times 0.23 \mathrm{~mm} \times 0.25 \mu \mathrm{m})$. The injection was performed in Split mode (30:1) with the SPME device, using the Adams, Wiley and NIST databases

\subsection{Antimicrobial activity of Z. Caribaeum Lam extracts}

The Kirby-Bauer [14] method was used to evaluate the antimicrobial activity of ethanolic extracts of leaves and bark of Z. caribaeum against the pathogenic microorganisms Burkholderia glumae. The antimicrobial activity of the ethanolic extracts of leaves and bark of Z. caribaeum was quantitatively evaluated for the presence of halos of inhibition and was statistically analyzed. In petri dishes with King $\mathrm{B}$ medium, the sensidiscs (sterilized filter paper) impregnated with $20 \mu \mathrm{L}$ of the concentrated extract (T1) and dilutions 1:1 (T2), 1:2 (T3), 1:4 (T4) (concentrated extract: ethanol), positive control (+) (STARNER (oxolinic acid), Sumitomo Chemical Co. Ltd) and negative control (-) (distilled water) were placed separately. Petri dishes were incubated at $30^{\circ} \mathrm{C}$ for $36 \mathrm{~h}$, and the diameters of the resulting inhibition halos were measured Statistical analysis (ANOVA) and Tukey's multiple comparison tests $\alpha$ $=0.05$ were performed with the SPSS program for MAC version 24. Each trial consisting of 6 repetitions for statistical validation.

\section{Results and discussions}

\subsection{Chromatographic profile by Thin Layer Chromatography (TLC)}

TLC profile of the ethanolic extract of $Z$. Caribaeum leaves was performed using different mobile phases. The best separation was obtained with petroleum ether: ethyl acetate (7:3). The profiles are shown in Table 1. Bands with fluorescent yellow and light blue colorations indicate the presence of flavones, flavonones, isoflavones, certain coumarins and alkaloids; red and fuchsia the presence of sesquiterpenes and terpenoids [15]. Confirmation of the presence of these metabolites was carried out with specific phytochemical assays for these metabolites, the results are shown in Table 2

Table 1. Solvent system and ratio for proper separation of secondary metabolites by Thin Layer Chromatography (TLC)

\begin{tabular}{|c|c|c|}
\hline Solvent system & Ratio & TLC \\
\hline & & \\
Hexane: Ethyl acetate & & \\
& & \\
& & \\
Ethyl acetate: Propanol & $9: 1$ & \\
\hline & & \\
\hline
\end{tabular}




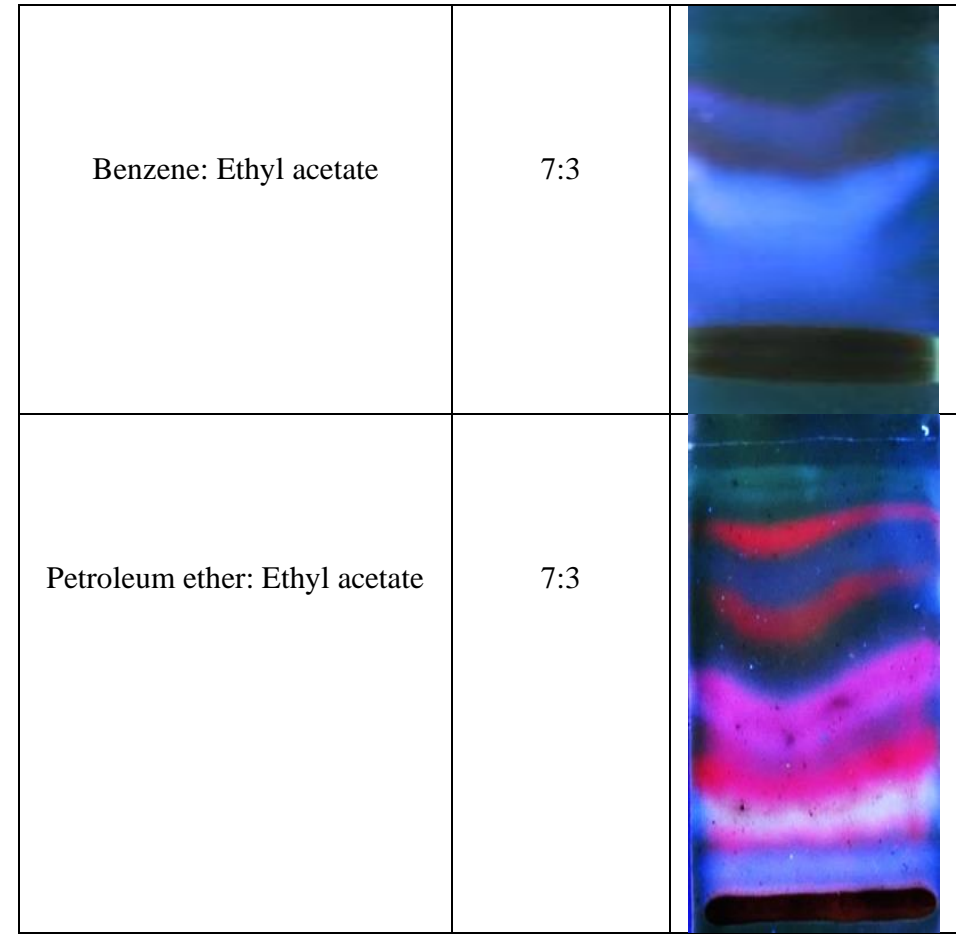

\subsection{Phytochemical screening of the plant extract}

Phytochemical screening of Z. caribaeum leaves was done from ethanolic extracts. Ethanol is a solvent with the ability to extract compounds with a wide range of polarities (polar and non-polar), it is economical and non-toxic. The identification of secondary metabolites was carried out using a modified protocol based on methodologies and qualitative tests [15], which are summarized in Table 2. The phytochemical screening of the ethanolic extract of Zanthoxylum caribaeum leaves has a similarity with the reports of Ordaz and collaborators [16], who detected in this same species alkaloids, phenols such as coumarins and tannins such as flavonoids in low proportion.

Table 2. Metabolites identified in ethanolic leaf extracts of Zanthoxylum caribaeum.

Presence of the secondary metabolite (+). Absence of the secondary metabolite (-)

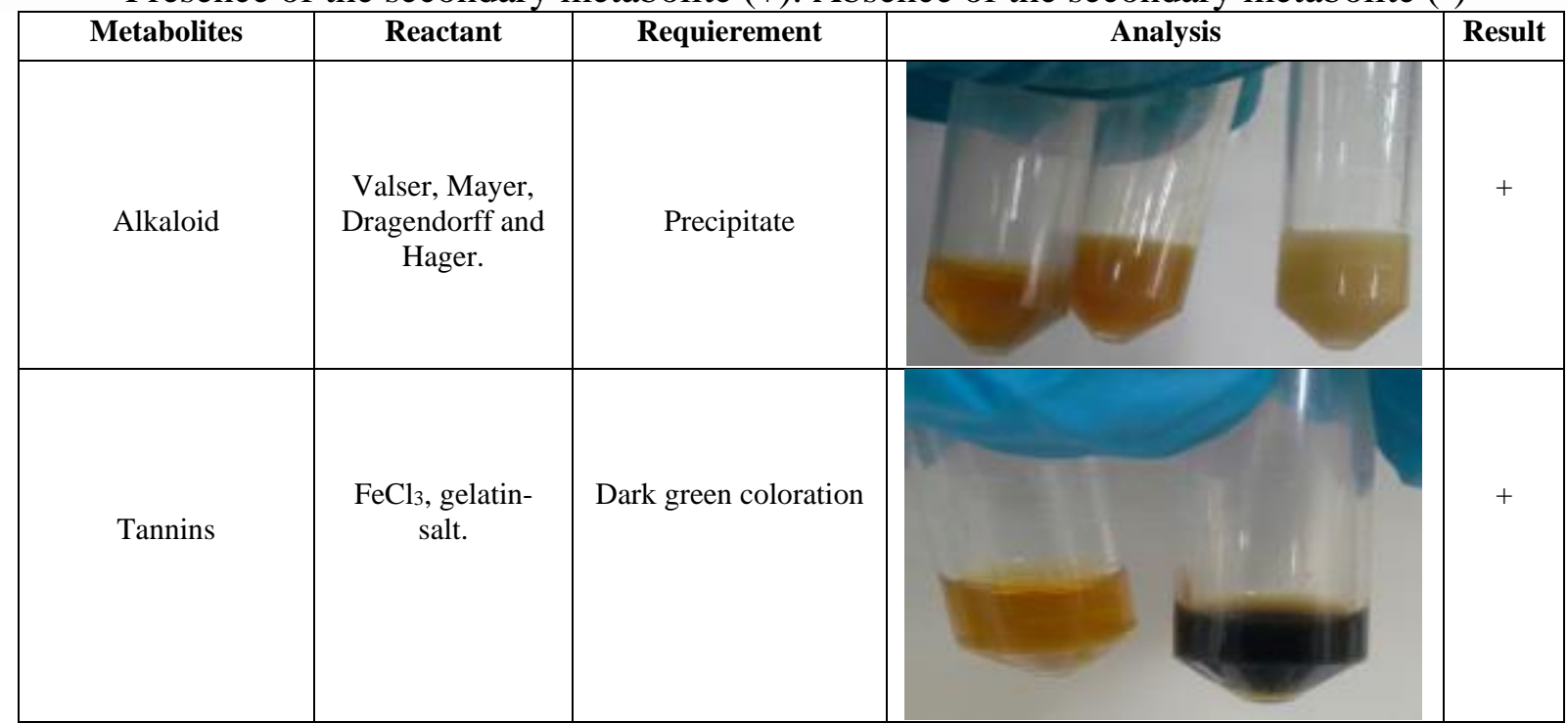




\section{Revista de Chimie}

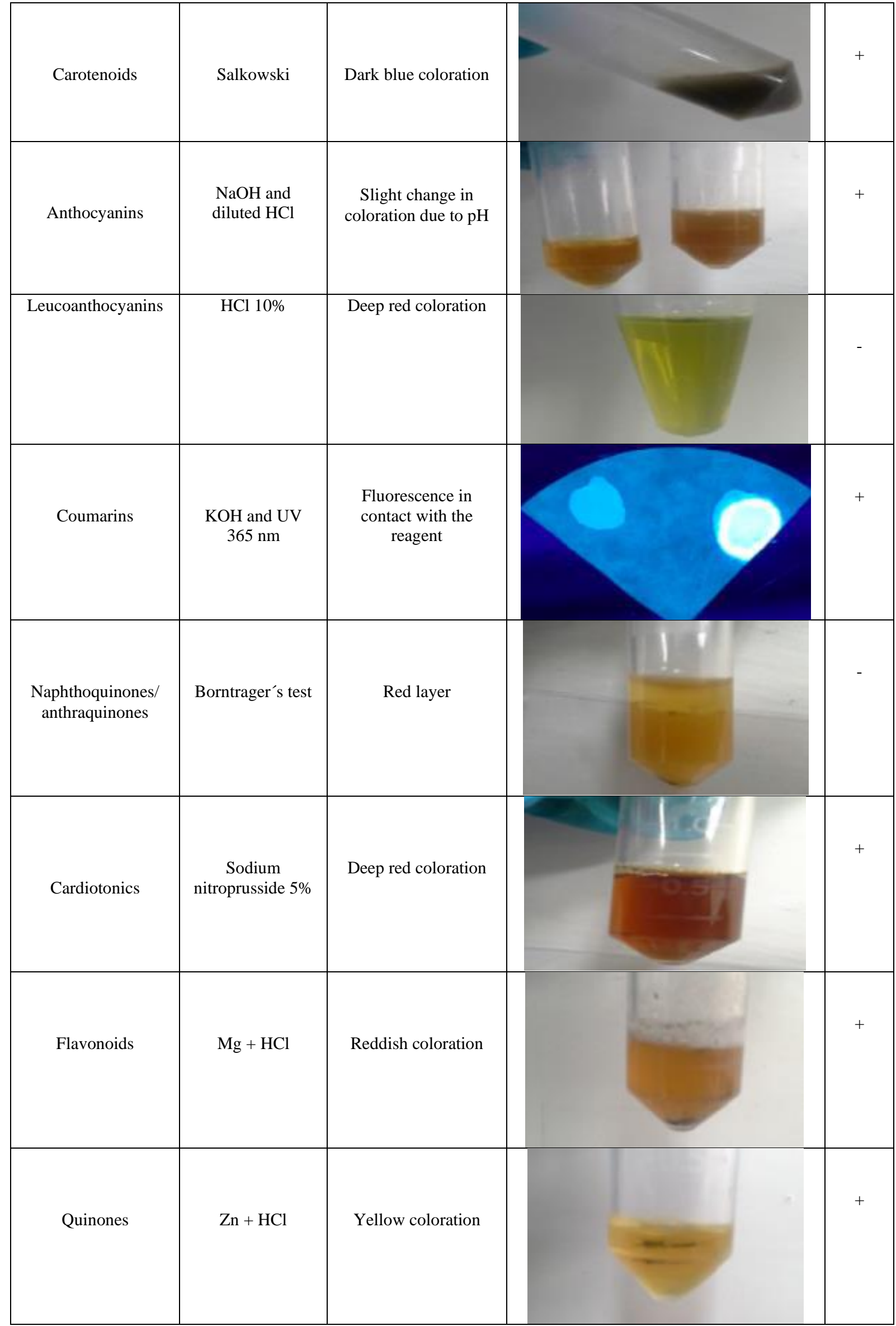




\section{Revista de Chimie}

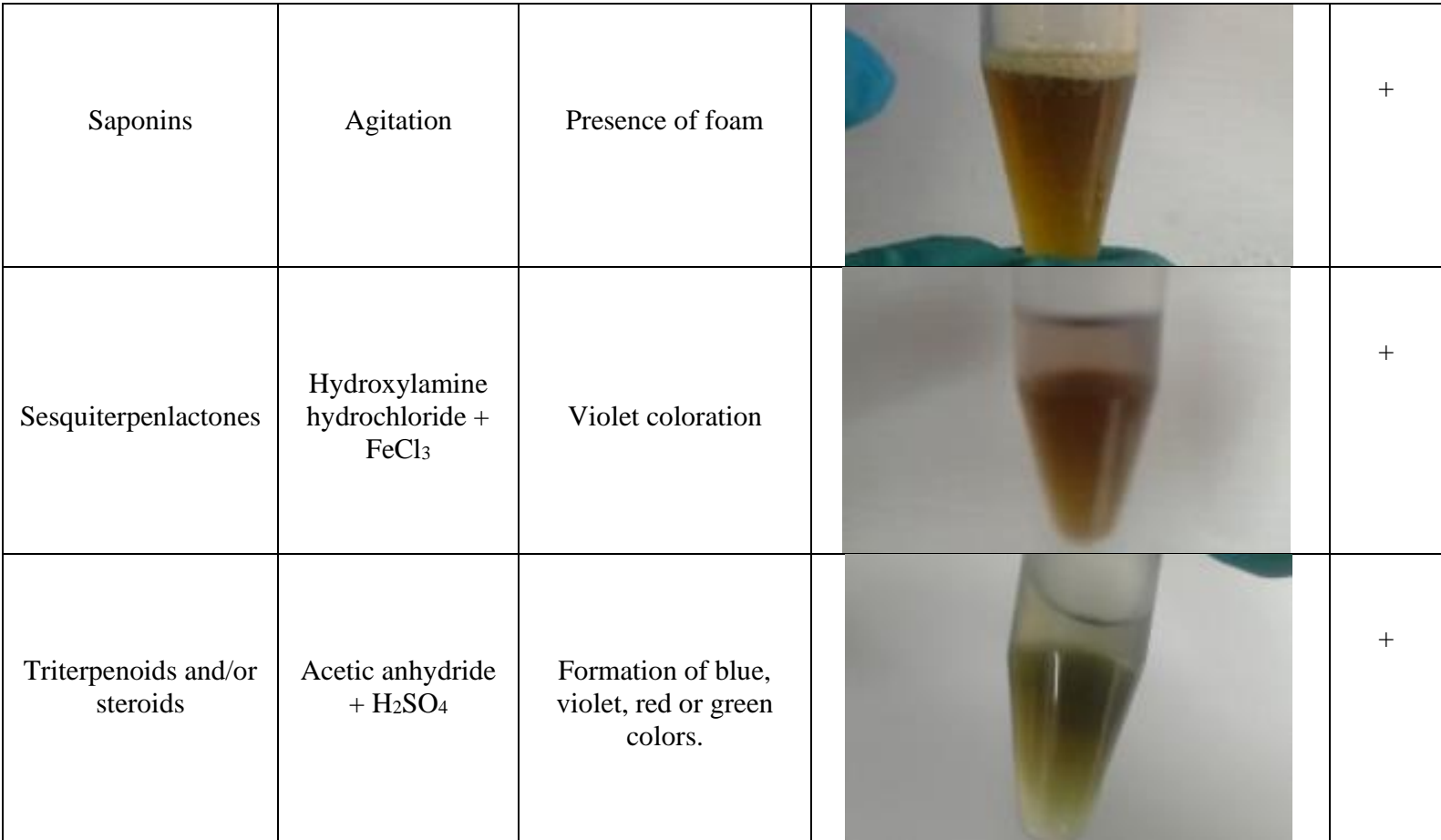

Once the best separation condition of the metabolites was obtained, their Rf values were determined by visualizing them with UV at 302 and $365 \mathrm{~nm}$ (Table 3).

Table 3. Chromatographic profile of secondary metabolites of $Z$ caribeaum leaves by thin layer chromatography wit petroleum ether: ethyl acetate $(7: 3)$

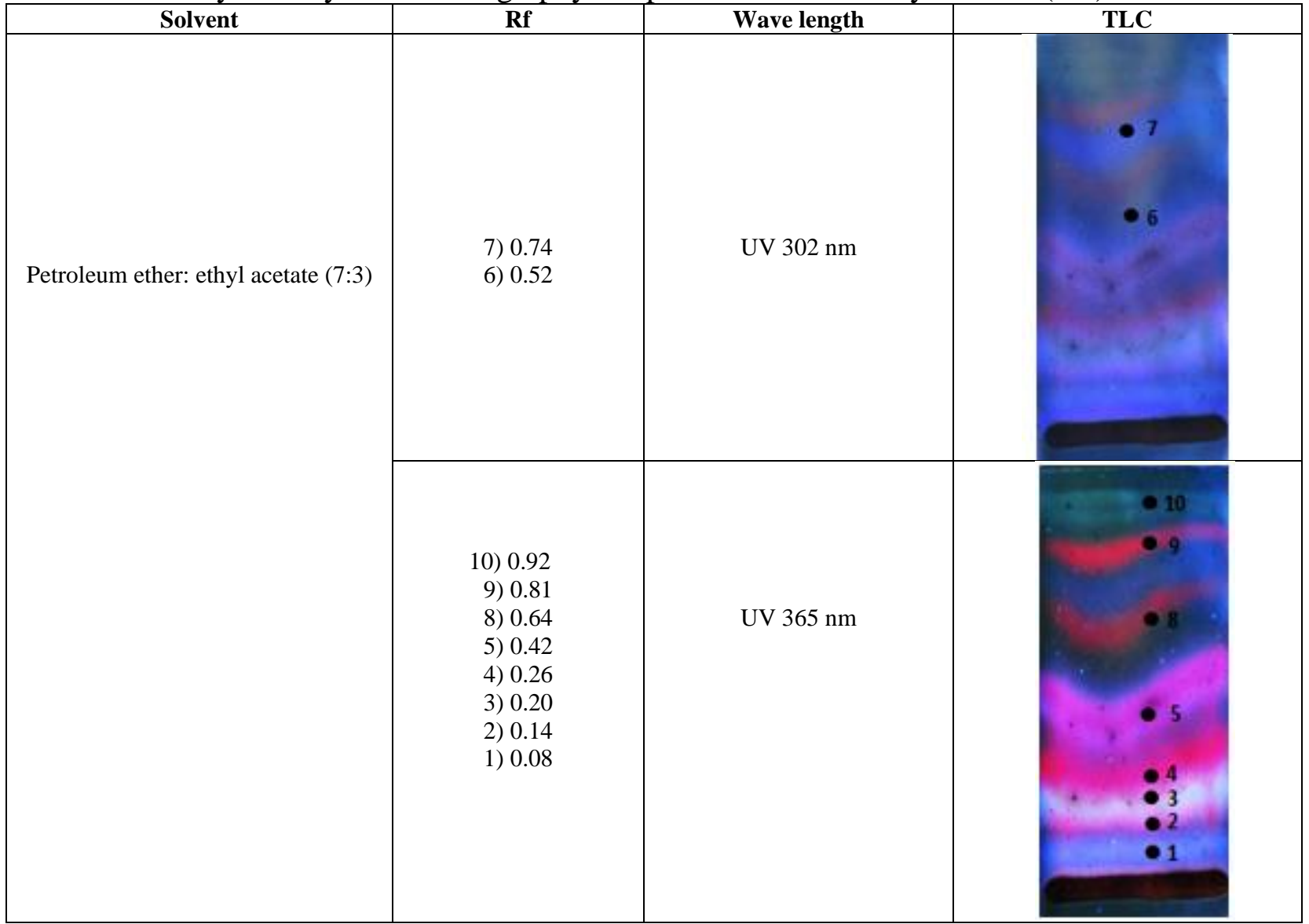


TLC test showed the presence of flavonoids with the appearance of reddish bands (RF 0.1 - 0.9) and celestial bands (RF 0.74), as shown in Table 4. This result was reconfirmed with the phytochemical screening using the Shinoda's test, obtaining reddish coloration, being positive for the presence of flavonoids type dihydroflavonols, precursors of flavonols. These compounds are used by the plant as a defense mechanism and attraction of pollinators. They also have antioxidant and free radical eliminator properties $[17,18]$.

\subsection{Gas Chromatography-Mass Spectrometry (GC-MS)}

Most of the compounds identified by GC-MS of the foliar extract of Zanthoxylum caribaeum correspond to of 15 -carbon sesquiterpenes, including trans- $\beta$-caryophyllene $(28.1 \%), \alpha$-humulene (3\%), $\gamma$-muurolene $(8.1 \%)$, valencene $(3.1 \%), \alpha$-trans-farnesene $(33.5 \%), \gamma$-cadinene $(2.8 \%)$, S-cadinene $(9.7 \%)$, calamenene $(1.2 \%)$, caryophyllene oxide $(8.3 \%)$, others not identified $(2.1 \%)$ (Table 5). The most abundant volatile secondary metabolites found were $\alpha$-trans-farnesene and trans- $\beta$-karyophyllene. The chemical structures of these compounds are shown in Figure 2.

(t)

Figure 2. Structures of some compounds identified by GC-MS in the leaf extact of Zanthoxylum caribaeum from Norte de Santander

Bioactivity studies have shown that many sesquiterpenes act as phytoalexins (antibiotics produced by plants in response to the attack of microorganisms) and as repellent agents of herbivores (Tripathi, et al., 2009). The results of the analysis of Zanthoxylum caribaeum from Norte de Santander (Table 4) are different from what was reported for the same plant sampled in the National Park Restringa in Rio de Janeiro, brazil [7, 9]. In example, they found trans- $\beta$-karyophyllene, $\alpha$-humulene, and $\gamma$-muurolene in much lower amounts; the trans- $\beta$-karyophyllene, was found in a proportion 6 times higher in the samples analyzed from Norte de Santander compared to what was reported in Brazil.

Table 4. Major compounds obtained from Zanthoxulum caribaeum leaf methanolic extract by GC-MS

\begin{tabular}{|c|c|c|}
\hline $\mathrm{T}_{\mathrm{R}},(\mathrm{min})$ & Compound & Relative amount, $\%$ \\
\hline 36.91 & Trans- $\beta$-Caryophyllem & 28.1 \\
\hline 38.13 & $\alpha$-Muurolene & 3.0 \\
\hline 38.64 & $\gamma$-Muurolene & 8.1 \\
\hline
\end{tabular}




\begin{tabular}{|c|c|c|}
\hline 39.23 & Valencene & 3.1 \\
\hline 39.32 & a-trans-Farnesene & 33.5 \\
\hline 39.89 & $\gamma$-Cadinene & 2.8 \\
\hline 39.98 & S-Cadinene & 9.7 \\
\hline 40.11 & Calamenene & 1.2 \\
\hline 42.07 & Caryophyllene oxide & 8.3 \\
\hline
\end{tabular}

Differences in chemical composition and relative quantities between plants of the same species from different localities may be due to geobotanical conditions or soil type [19]. Among the compounds found, trans- $\beta$-karyophyllene (relative amount of $28.1 \%$ in Z. caribeaum from Norte de Santander) has antiparasitic activity against Leismania and has been suggested as an attractive and safe molecule for the development of drugs against this protiste [20]. Cytotoxic activity of Lippia origanoides essential oil was also reported with a relative amount of $9.4 \%$ trans- $\beta$-cariophyllene on HeLa cells [21]. Finally, it has been reported that caryophyllene oxide, used as a preservative for food, medicines and cosmetics, has antifungal activity against dermatophytes [22]. The most abundant compound in the leaves of Zanthoxylum caribaeum from Norte de Santander is $\alpha$-trans-farnesene with a relative amount of 33.5\% (Table 4). The $\alpha$-farnesene is found in the coating of apples and other fruits and is responsible for the characteristic smell of the green apple [23]. Its oxidation by air forms compounds that are harmful to fruit. Oxidation products injure cell membranes that eventually cause death in the outer cell layers of the fruit [24]. The effect of antimicrobial activity against different types of bacteria is attributed to $\alpha$ farnesene among other compounds [25]. Finally, the essential oil of Ocimum gratissimum leaves with the compounds $\gamma$-muurolene and $\alpha$-farnesene, has antibacterial properties against certain pathogens that cause gastroenteritis. It is suggested that the oil alters the cytoplasmic membrane of microorganisms [26].

\subsection{Effect of ethanolic extracts of Z. caribaeum leaves against Burkholderia glumae}

Regarding the antibacterial activity of the ethanolic extract of $Z$. caribaeum it was found that the greatest halo of inhibition against B. Glumae occurs with dilution E (1:4). Dilutions B (1:0), C (1:1), and D (1:2) showed inhibition halos less than $0.5 \mathrm{~mm}$ with respect to the positive control with a halo of $10.7 \mathrm{~mm}$ in diameter (Figure 3).

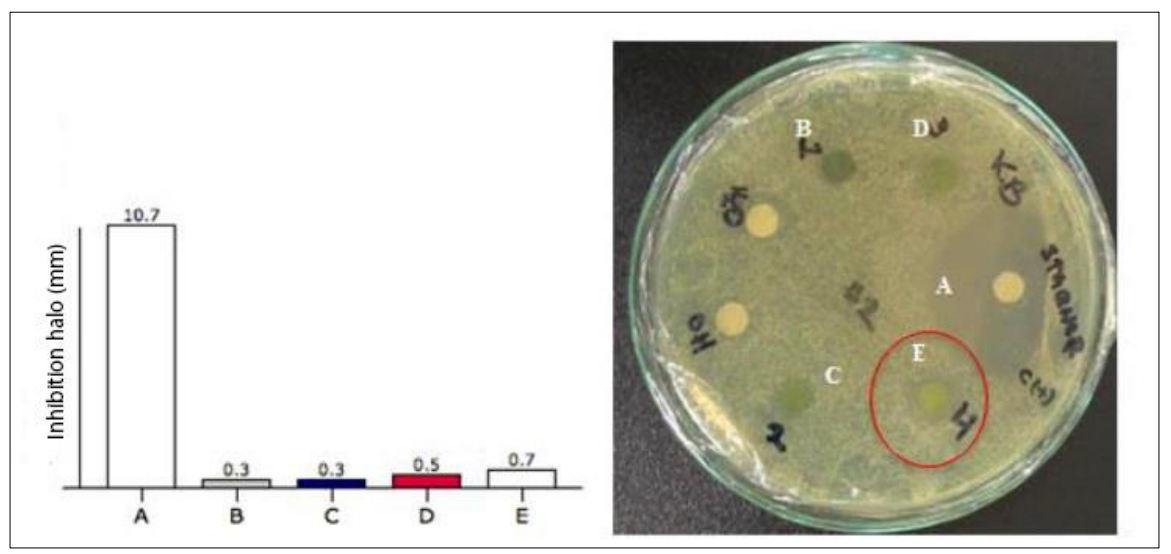

Figure 3. Antibacterial activity of dilutions of Z. caribaeum leaf extract in ethanol

(extract:ethanol) against Burkholderia glumae. A) Positive control STARNER 0.250mg/mL, B)

Dilution 1:0, C) Dilution 1:1, D) Dilution 1:2, E) 1:4. The treatments present significant differences $\mathrm{P}<0.05$ with the Tukey test. $\mathrm{n}=6$. The bars represent the confidence intervals for $\alpha=0.05$

The antimicrobial activity was measured in millimeters $(\mathrm{mm})$, determining as weakly active those extracts that presented 5 to $10 \mathrm{~mm}$ in diameter, moderately active those that showed an inhibition of 10 to $20 \mathrm{~mm}$, and highly active those that presented antibacterial activity above $20 \mathrm{~mm}$. Figure 4 shows the 
negative control (water). Significant differences are presented with the dilution of the extract 1:4 (E) with an inhibition halo of $0.7 \mathrm{~mm}$.

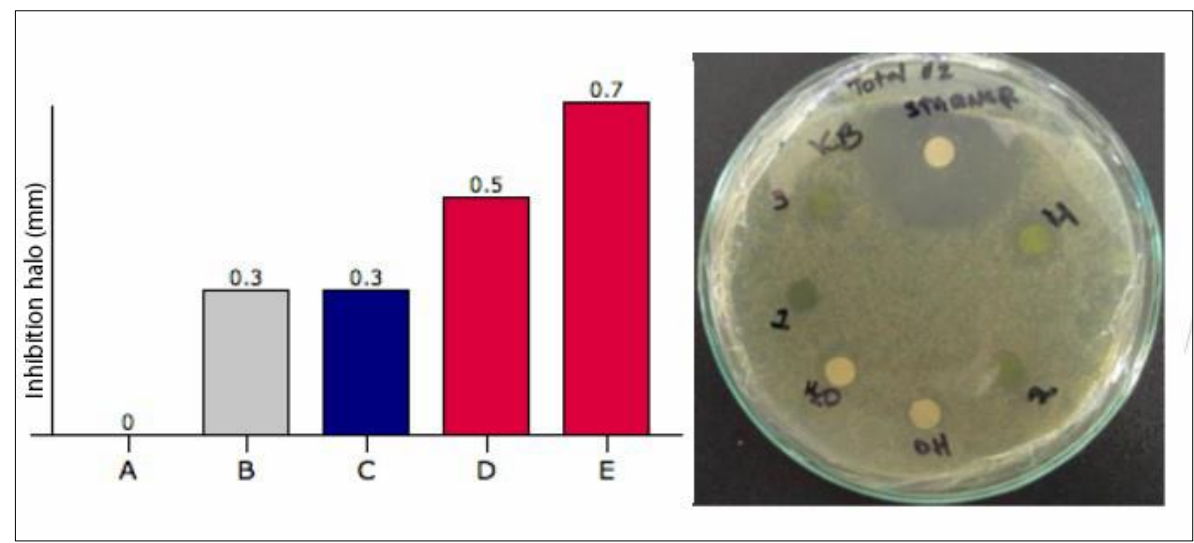

Figure 4. Antibacterial activity of dilutions of $Z$. caribaeum leaf extract in ethanol (extract:ethanol) against Burkholderia glumae. A) Negative control water B) Dilution 1:0,

C) Dilution 1:1, D) Dilution 1:2, E) 1:4. The treatments present significant differences

$\mathrm{P}<0.05$ with the Tukey test. $\mathrm{n}=6$. The bars represent the confidence intervals for $\alpha=0.05$

The results indicate that the ethanolic leaf extract of $Z$. caribeaum has no significant biological activity against $B$. glumae, a Gram-negative bacterium, confirming recently studies in Gram-positive bacteria pathogenic to man [9].

\section{Conclussions}

The present study shows the presence of important secondary metabolites in Z. caribeaum plants in Norte de Santander, Colombia. Although ethanolic leaf extracts have no inhibitory effects on the Gramnegative bacterium $B$. glumae, the richness of biologically active compounds present in $Z$. caribeaum samples suggest the high potential of this plant as a source of new drugs or compounds of chemical or pharmaceutical importance.

Aknowledgments. We thank to "Fondo de Investigaciones Universitarias" (FINU) from the Universidad Francisco de Paula Santander for financing the project 032-2017

\section{References}

1.COMPEAN KL, YNALVEZ RA. Antimicrobial activity of plant secondary metabolites: A review, Research Journal of Medicinal Plants. 8(5), 2014, 204-213. doi:10.3923/rjmp.2014.204.213.

2.HUSSEIN R, EL-ANSSARY A. Plants Secondary Metabolites: The Key Drivers of the Pharmacological Actions of Medicinal Plants. In: Buikders P, editor. Herbal Medicine. IntechOpen, 2018. doi:10.5772/intechopen.76139.

3.MILTON JRP. Phylogeny of Rutaceae based on two noncoding regions from cpDNA, American journal of botany. 95(8), 2008, 985-1005. doi:10.3732/ajb.2007313.

4.COY B, CUCA SLE. Metabolitos aislados de raputia heptaphylla y esenbeckia alata (rutaceae) y síntesis de precursores de análogos de alcaloides quinolínicos, Elementos. 5(5), 2015, 9-21.

doi:10.15765/e.v5i5.617.

5.BARRERA CA, PARRA J, CUCA LE. Caracterización química del aceite esencial e identificación preliminar de metabolitos secundarios en hojas de la especie raputia heptaphylla (rutaceae), Elementos. 4(4), 2014, 31-39. doi:10.15765/e.v4i4.513.

6.OWUSU E, OSAFO W, NUTSUKPUI E. Bioactivities of candlewood, Zanthoxylum Xanthoxyloides (lam.) solvent extracts against two stored-product insect pests, African Journal of Science and Technology. 8(1), 2007, 17-21. 
7.NOGUEIRA J, VINTURELLE R, MATTOS C, TIETBOHL LA, SANTOS MG, JUNIOR IS, et al., Acaricidal properties of the essential oil from Zanthoxylum caribaeum against Rhipicephalus microplus, J Med Entomol. 51(5), 2014, 971-5. doi:10.1603/me13236.

8.DORLA E, GRONDIN I, HUE T, CLERC P, DUMAS S, GAUVIN A, et al., Traditional uses, antimicrobial and acaricidal activities of 20 plants selected among Reunion Island's flora, South African Journal of Botany. 1222019, 447-456. doi:https://doi.org/10.1016/j.sajb.2018.04.014

9.ORTEGA-BUITRAGO O, CHAVES-BEDOYA G, ORTIZ-ROJAS LY. Chemical Composition and Antimicrobial Activity of Ethanolic Bark and Leave Extract of Zanthoxylum Caribaeum Lam. from Norte de Santander, Colombia, Rev. Chim., 72(4), 2021, 152-161

10.FLOREZ-CARMONA M, CRUZ-ORTEGA R, ANAYA A. Allelopathic potential of some tropical trees of Ecological Reserve El Eden, Quintana Roo, Mexico, Allelopathy Journal. 21(1), 2008, 57-72.

11.GOMEZ Y, GIL K, GONZÁLEZ E, FARÍAS L. Actividad antifúngica de extractos orgánicos del árbol Fagara monophylla (Rutaceae) en Venezuela, Revista de Biología Tropical. 55(3-4), 2007, 767775.

12.RIOS MY, CORDOVA-ALBORES LC, RAMIREZ-CISNEROS MA, KING-DIAZ B, LOTINAHENNSEN B, LEON RIVERA I, et al., Phytotoxic Potential of Zanthoxylum affine and Its Major Compound Linarin as a Possible Natural Herbicide, ACS Omega. 3(11), 2018, 14779-14787.

doi:10.1021/acsomega.8b02020.

13.ORTEGA L, ROJAS CM. Bacterial Panicle Blight and Burkholderia glumae: From Pathogen Biology to Disease Control, Phytopathology. 111(5), 2021, 772-778.

doi:10.1094/PHYTO-09-20-0401-RVW.

14.BAUER AW, KIRBY WM, SHERRIS JC, TURCK M. Antibiotic susceptibility testing by a standardized single disk method, Am J Clin Pathol. 45(4), 1966, 493-6.

doi:https://doi.org/10.1093/ajcp/45.4_ts.493

15.MARTINEZ A, VALENCIA G, JIMENEZ N, MESA M, GALEANO E. Manual de practicas de laboratorio de farmacognosia y fitoquimica. In: Universidad de Antioquia Ddf, editor. Medellin, Colombia: 2008.

16.ORDAZ C, GARCES R, LOPEZ M, DE LA GARZA M, ARRIAGA-ALBA M. Estudio de mutagenicidad y actividad antibacteriana de Erythrina herbacea, Zanthoxylum caribaeum y Dendropanax arboreus, Rev Mex Cienc farm. 45(1), 2014, 78-85.

17.SAEED N, KHAN MR, SHABBIR M. Antioxidant activity, total phenolic and total flavonoid contents of whole plant extracts Torilis leptophylla L, BMC Complement Altern Med. 122012, 221. doi:10.1186/1472-6882-12-221.

18.SHI P, DU W, WANG Y, TENG X, CHEN X, YE L. Total phenolic, flavonoid content, and antioxidant activity of bulbs, leaves, and flowers made from Eleutherine bulbosa (Mill.) Urb, Food Sci Nutr. 7(1), 2019, 148-154. doi:10.1002/fsn3.834.

19.ORTIZ-ROJAS LY, CHAVES-BEDOYA G. Phytochemical composition of the root extract of Ichthyothere terminalis from two geographical regiones in Colombia, Revista Colombiana de Quimica. 46(3), 2017, 11-16. doi:https://doi.org/10.15446/rev.colomb.quim.v46n3.61865

20.SOARES D, PORTELLA N, RAMOS M, SIANI A, SARAIVA E. Trans- $\beta$-Caryophyllene: An Effective Antileishmanial Compound Found in Commercial Copaiba Oil (Copaifera spp.) Evid Based Complement Alternat Med. 2013, 761323. doi:10.1155/2013/761323.

21.ZAPATA B, C. D, STASHEMKO E, CORREA-ROYERO J, BETANCUR-GALVIS L. Actividad citotóxica de aceites esenciales de Lippia origanoides H.B.K. y componentes mayoritarios, Revista Salud UIS. 41(3), 2009, 215-222.

22.YANG D, MICHEL L, CHAUMONT P, MILLET-CLERC J. Use of caryophyllene oxide as an antifungal agent in an in vitro experimental model of onychomycosis Mycopayhologia. 148(2), 1999, 79-82. doi:10.1023/a:1007178924408.

23.HUELIN FE, MURRAY KE. Alpha-farnesene in the natural coating of apples, Nature. 210(5042), 1966, 1260-1. doi:10.1038/2101260a0. 
24.ALAMGIR ANM. Chapter 3. Secondary metabolites: Secondary metabolic products consisting of C and $\mathrm{H} ; \mathrm{C}, \mathrm{H}$ and $\mathrm{O} ; \mathrm{N}, \mathrm{S}$, and $\mathrm{P}$ elements; and $\mathrm{O} / \mathrm{N}$ heterecycles. In: Therapeutic Use of Medicinal Plants and their Extracts: Volume 2. Switzerland: Springer International Publishing, 2018. p. 174.

25.GOVINDEN-SOULANGE J, MAGAN N, GURIB-FAKIM A, GAUVIN A, SMADJA J, KODJA $\mathrm{H}$. Chemical composition and in vitro antimicrobial activities of the essential oils from endemic Psiadia species growing in mauritius, Biol Pharm Bull. 27(11), 2004, 1814-8. doi:10.1248/bpb.27.1814. 26.CHIMNOI N, REUK-NGAM N, CHUYSINUAN P, KHLAYCHAN P, KHUNNAWUTMANOTHAM N, CHOKCHAICHAMNANKIT D, et al., Characterization of essential oil from Ocimum gratissimum leaves: Antibacterial and mode of action against selected gastroenteritis pathogens, Microb Pathog. 1182018, 290-300. doi:10.1016/j.micpath.2018.03.041.

Manuscript received: 27.09 .2021 